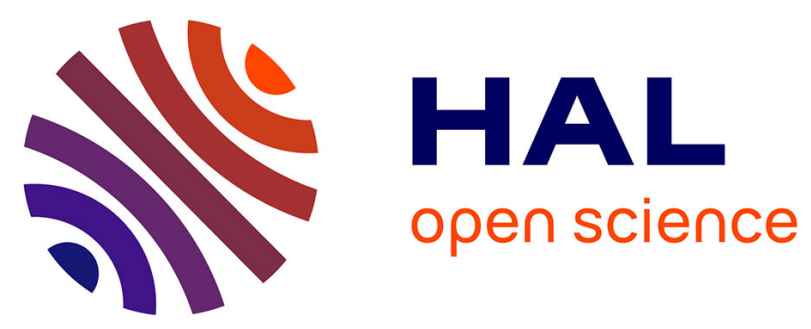

\title{
LEGAL CLASSIFICATION OF TYPES OF INFORMATION ABOUT AN INDIVIDUAL
}

\author{
Anatoliy Kostruba, Hans Joachim Schramm
}

\section{To cite this version:}

Anatoliy Kostruba, Hans Joachim Schramm. LEGAL CLASSIFICATION OF TYPES OF INFORMATION ABOUT AN INDIVIDUAL. Journal of the National Academy of Legal Sciences of Ukraine, 2019, 26 (1), pp.124-132. 10.31359/1993-0909-2019-26-1-123 . hal-02377538

\section{HAL Id: hal-02377538 \\ https://hal.science/hal-02377538}

Submitted on 23 Nov 2019

HAL is a multi-disciplinary open access archive for the deposit and dissemination of scientific research documents, whether they are published or not. The documents may come from teaching and research institutions in France or abroad, or from public or private research centers.
L'archive ouverte pluridisciplinaire HAL, est destinée au dépôt et à la diffusion de documents scientifiques de niveau recherche, publiés ou non, émanant des établissements d'enseignement et de recherche français ou étrangers, des laboratoires publics ou privés. 
УДК 347.155

DOI: 10.31359/1993-0909-2019-26-1-123

\author{
Ханс Іоахім Шрамм \\ Iнститут Східного права \\ Університет технологій, бізнесу та дизайну \\ Вісмар, Німеччина
}

\author{
Анатолій Володимирович Коструба \\ Кафедра иуивільного права \\ Прикарпатський наиіональний університет імені Василя Стефаника \\ Івано-Франківськ, Україна
}

\title{
ПРАВОВА КЛАСИФІКАЦІЯ ВИДІВ ІНФОРМАЦІЇ ПРО ФІЗИЧНУ ОСОБУ
}

Анотація. Прочеси використання, поширення, зберігання інформації сприяють виникненню інформаційних правовідносин. Тому основна мета роботи полягає у аналізі правової класифікачії видів інформачії про фізичну особу. Встановлено, щуо сочіальна правова держава зобов'язана забезпечити інформаційні права громадян як на отримання доступу до інформації, так і стосовно нерозповсюдження певних видів даних для захисту прав їх власників. Автором було сформовано власний погляд на класифікацію персональних даних фізичної особи в ијивільному праві Украӥни. Виявлено, щуо правова природа персональних даних фізичної особи полягає в тому, щуо останні складає інформація - як сукупність відомостей про певні події, явища, стан тощо. Ця інформація індивідуалізує суб' 'ккта права - фізичну особу, який в свою чергу наповнює ї̈ певним змістом. Загальновідомим є той факт щзо фізична особа як суб' єкт циивільних правовідносин має суспільні і природні ознаки, які впливають на його правовий статус і певним чином індивідуалізують його. До біологічних персональних даних слід віднести відомості про морфофізіологічні, біохімічні і психологічні ознаки особи. Соціальні персональні дані складаються із відомостей про сімейний стан, рівень освіти тощо. Запропоновано встановити наступну класифікацію: номінативні персональні данні фізичної особи, якими є прізвище, ім'я, по батькові, дата народження тощчо як базисна умова їх класифікаиіï, а також варіативні персональні дані фізичної особи - освіта, сімейний стан, місие проживання тощо, за допомогою яких встановлюється змістовність інформації про особу, досягається можливість чіткішій ідентифікації індивідуума в «правовому полі». Їх мета первісно визначити суб 'єкта на підставі його загальної характеристики. Варіативні персональні дані можуть накопичуватися або змінюватися під впливом обставин дійсності, наприклад, за минулістю часу. Консолідуючись з номінативними, вони сприяють досягненню мети персоніфікації фізичної особи чим забезпечується обігоздатність інформації про фізичну особу.

Ключові слова: персональні дані, документована інформація, біометричні персональні дані, немайнові правовідносини. 
Hans Joachim Schramm

Institute of Eastern Law

University of Technology, Business and Design

Wismar, Germany

Anatoly V. Kostruba

Department of Civil Law

Vasyl Stefanyk $P_{\text {recarpathian National University }}$

Ivano-Frankivsk, Ukraine

\title{
LEGAL CLASSIFICATION OF TYPES OF INFORMATION ABOUT AN INDIVIDUAL
}

\begin{abstract}
The processes of use, distribution, storage of information contribute to the emergence of information relations. Therefore, the main purpose of the research is to analyze the legal classification of the types of information about an individual. It has been determined that the social legal state is obliged to ensure the information rights of citizens both to gain access to information and to non-proliferation of certain types of data in order to protect the rights of their owners. The author has formed his own view on the classification of personal data of an individual in the civil law of Ukraine. It is determined that the legal nature of the personal data of an individual is that this personal data is information as a collection of information about certain events, entities, status, etc. This information individualizes the subject of law - an individual who, in turn, fills it with certain content.
\end{abstract}

Keywords: personal data, documented information, biometric personal data, non-property relations.

\section{INTRODUCTION}

As individualized subject of civil law an individual is constantly in civil law relations with other subjects. Such legal connection is preceded by information about entities, events or legal status of things, with which parties intend to enter into civil legal relations. Certain roles in the formation of legal relations between subjects of law are also the content and flow of information about an individual, with the use of which it is possible to create one or another legal relation.

Despite the fact that the notion of the personal data is defined in Ukrainian legislation, its content and classification need to be clarified. Thus, article 2 of Ukrainian law "On personal data protection" states that personal data is data or collection of information about the physical person who is identified or can be specifically identified [1]. At the same time, this legal act does not disclose the content of such data. There are no details of data classification about an individual (personal data) in article of law of Ukraine "On information" [2]. It contains the open list of such information as data on nationality, education, marital status, religious beliefs, state of health, as well as address, date and place of birth, etc. 
Analysis of scientific researches concerning this topic also does not give a full answer to the question about classification and content of data about an individual (personal data). Thus, scientists such as V. Bridzhko, O. Kulinich, E. Petrov, A. Chernobay paid attention to the study of the issues of the protection of the right to privacy, the flow of personal data of an individual, but they were more focused on the organization of the processing of personal data in the sphere of public legal relations.

At the same time, the uncertainty regarding the classification of personal data of an individual may lead to a violation of the rights of the latter, in the case of dissemination of data that is not included in the list established by the current legislation of Ukraine, but significantly affect the identity of its owner. This is due to the fact that the individual independently determines the degree of influence of the dissemination of information about him and his spiritual state. This determines the relevance of the study of this issue in the context of its private legal regulation.

The purpose of the article is to disclose types of information about an individual (personal data) and create their legal classification on the basis of the established criteria.

Therefore, information about an individual (personal data) is specific information about subjective civil rights and legal obligations of a person, or his/her legal status, which ensure the legal personification of an individual.

\section{MATERIAL AND METHODS}

The processes of democratization of the power relations system and the state mechanism of Ukraine at the present stage provide the legal regulation of information openness of state authorities and local self-government bodies. For a more detailed study of the question, the author used a variety of theoretical methods. The analysis of modern foreign legislation in the field of information relations allows distinguishing the following characteristic features that provide public access to public information:

- acts that regulate public access to public information are constitutional;

- all public information with a few exceptions is accessible for media, scientific organizations, parties, citizens;

- the list of information, which is secret, is determined by law;

- departmental specification of secret data is allowed in exceptional cases, subject to approval by parliament;

- both citizens of the state and foreigners have access to public information;

- officials are obliged to provide information about their activities.

The method of analysis also allowed to find that the growing demand for information leads to the dividing information activities into a separate form that results in appearing of intangible objects of legal relations. The mentioned actualizes the problem of scientific research concerning the protection and defense of information resources in databases, in particular in the aspect of ownership of information. Therefore, scientific research includes certain sequence of actions, methods, operations, which contribute to learning of objective reality. 
Through the methodological basis there were determined basic notions that explain scientific events and disclose patterns. The methodological basis of scientific research means the basic, initial provisions on which it is based. There were determined patterns and mechanisms of legal classifications of types of information about an individual.

\section{RESULTS AND DISCUSSION}

\subsection{Features of classification of property and non-property relations}

With a view to hermeneutic clarity, the author equates the notions of information about an individual, record about an individual and the notion of personal data of an individual, because their legal sense is an individual identification. In order to disclose the content of this data, criteria of their legal classification, we turn to legal nature of information about an individual (personal data).

All existing in civil society relations are conventionally divided into two groups. When implementing the first of them, the subjects interact with each other in order to change the state of physical substance which forms the object of such relations. They are property (alienation of property or its creation, temporal transfer of this property to another person, etc.).

The essence of the second group is interaction of subjects without material component of these relations. R. O. Halfina paid attention that there are such relations in law [3]. Their sense is spiritual life of human, a purpose of which is satisfaction of physiological, cultural, social needs, etc. The multifaceted nature and diversity of personal non-property legal relations is explained by the theoretical doctrine of natural law and disclosed by the theory of plurality of personal rights, which is currently supported by the majority of scholars [4]. Its general meaning is that the diversity of personal nonproperty interests influences the diversity of civil-law forms of mediation.

This is absolutely reasonable because the evolution of humankind conduces changes, improvements or cessation of human everyday needs. They are in constant dynamics. Their amount cannot be clearly regulated by the current legislation of Ukraine. The state establishes an "open" list of general human rights and freedoms, which is not limited to the norms of the constitutional law of Ukraine. He has a certain level of abstraction. Consequently, the amount of personal non-property relations is not exhausted. Their type classification has no sense. Only generic classification of personal non-property rights is expedient. Its purpose is to determine inside-system patterns of development of non-property rights, mastering the theoretical and legislative material in their legal regulation.

Mane scientists paid attention to the matter of classification of personal non-property relations $[5 ; 6 ; 7]$. The author consider expedient to adopt the classification provided by N. O. Davydova. It is based on the activities of the subject of law, aimed at achieving the goal, which is the basis of the instrumental approach in jurisprudence that 
receives a significant spread in law of the present. The initiative in applying certain decisions is a feature that allows taking into account the instrumental approach, based on the assessment of human choice of the implementation of the solution in its own activities, within which this feature is able to work [4].

In such way, N. O. Davydova divides personal non-property relations into two groups: 1. Rights that provide the natural existence of an individual (right that provides well-being; right to liberty and security of person; right to marriage, family, care, etc.). 2. Rights that provide the social existence of an individual (the right to individualization of citizens in society, the rights that provide the autonomy of the individual (the privacy of personal life), the rights that protect the results of intellectual activity, the rights that contribute to the multilateral development of the individual and the expression of his creative personality, etc.) [4].

An amount of personal non-property rights is the competence of an individual - a subject of civil law to a certain legal behaviour in relation to the goods of immaterial nature, which are the object of law. The consent of such goods is information about status of things, entities or events that occur in a society and to which the subject has a direct legal interest. For example, the rights of personal life that provide privacy include a competence of the relevant subject to certain actions to protect them. In particular, these are the right to have the information about private life of the human, the savings, the protection or the promulgation. In such way, this information is indicated as the connection of the object with the category of interest and the needs of the subject.

At the same time, objects mean philosophical category that define any real or imaginary reality, which is considered as something external in relation to a person and becomes the subject of person's theoretical and practical activities. If to consider this phenomenon as a matter of law, the object is the search legal effect, the subject of legal control, which is achieved by the content of the law (or the content of legal relations) [8].

The presence of social or economic value strengthens the point of view that information about certain phenomena, state or events is considered as an object of law. This information reflects professional competence, ability to work and other social properties of a person. They characterise the individuality of each person as a carrier of unique elements of physical, physiological, psychological, economic, cultural or social identity that has a certain legal value.

From the social and philosophical perspective, this information is a reflection of the reality, which can be stored on physical media or displayed electronically. In such way, it is certain information about the subject of law, which reflects his or her individuality, social activity, and is the subject of civil law, receives legal protection against a possible violation by an uncertain circle of persons. Using information about an individual (personal data) person's competence, which provides the implementation of personal non-property rights, is formed. 


\subsection{The features of personal data}

Closely related to the identity of the possessor of a right, such information is a segment of the right to privacy guaranteed by art. 32 of the Constitution of Ukraine, that is, personal data is also the object of personal non-property legal relations. It should also be emphasised in the light of the foregoing the feature of personal data is its abstractness. The list of types of information about an individual (personal data) cannot be exhausted and has conditional nature.

There are many criteria to classify information as object of law. Some scientists insist that classification of information cannot be divided. On the contrary, it has to be single, integral and based on an integrated, systematic approach. Complexity, systematic classification involves the singling out and consideration of all possible types and types of information in civil law [9].

Typically, the classification depends on the purpose, which requires for achieving a more in-depth study of the subject through its classification.

According to V. G. Afanasiev as an object of law information can be divided into types on the following basis: 1) on the basis of its relation with the time in which it is created and used. Accordingly, information about the past, present and future is highlighted; 2) by the source of information social and political (including economic, family-household, etc.), scientific and technical, accounting and statistical information varies; 3 ) by the focus: horizontal information, the flows of which circulate between the authorities of one level, and vertical, circulating through vertical channels; 4) by the form of the material carrier: visual (visible, documentary) and sound (audible), teleinformation, newspaper, magazine, embodied in artistic works, etc .; 5) by the possibility of its repeated use: fixed (documented) - materialized on paper, electronic memory, etc. (can be used repeatedly) and unpublished (undocumented) - used once, at the moment of receipt [10].

V. N. Lopatin also suggests certain grounds to classify the information: 1) by the degree of organisation (ordering) - documents and other information; information resources and free information, which is not listed in information resources; systemized (catalogs, encyclopedias, rubrications, etc.) and not systemized information; 2) by the type of carrier (form of fixing) - on a paper carrier, video and sound, computer information, in volume and spatial form, oral, energy (biological) during energy information exchange; 3 ) by the function (by the scope of application) - mass information distributed through the media, industry, professional information of interest; 4) by degree of access - restricted information, information without restriction of access, intellectual property objects, "harmful information" with restrictions on distribution, other public information [11].

V. A. Kopylov classifies information basing on features of the legal regulation in information relations: 1) information as a result of art; (achievements, inventions, discoveries); 2) mass information containing informative messages; 3 ) documented information about citizens (personal data); 4) official documented information; 5) informa- 
tion, obligatory provided by legal entities and individuals in the order of reporting on their own activities; 6) information that is not the result of art, but is formed and distributed as a product; 7) information in the form of information resources as arrays (stocks) of retrospective information [12].

Undoubtedly, each of the mentioned classifications has its own scientific sense, because it allows disclosing a sense of certain information in different contexts, determining features of the legal regulation of this information. However, the given classification is of general theoretical nature. Unfortunately, it does not reveal functional meaning of such legal phenomena as personal data of an individual. It is about the role of this phenomenon in the micro mechanism of regulation of legal relations, in which personal data is their object. This allows determining features of legal regulation of personal data flow in civil legal relations, revealing their meaning.

In such way, classification made by N. I. Petrikina is very interesting. Depending on a legal regime of flow and a scope of application of personal data, she determines three types: publicly available personal data; special categories of personal data; biometric personal data. The first refers to the personal data, access to which provided by the person concerned. This information can be reported by an individual and the content of which is his daily social interaction. Special categories of personal data include information about race, national identity of a person, political views, religious beliefs, state of health, etc. Biometric personal data is information that characterises the physiological features of a person, on the basis of which it is possible to identify a person (blood group, DNA code, fingerprints, etc.) [13].

It should be emphasized that some researched suggest other variants of differentiation of only personal data. In particular, V. Y. Ishenkov divides it into following categories: physical, physiological, and relative personal data. Physical and physiological are a genus, DNA composition, digital external image, height, body weight, blood composition, etc. In relative author includes: place and date of birth, ethnic origin, social status, family status, number of children, place of birth, salary level, address and contact information, political views, etc. [14].

In general without denying the positions of mentioned scientists, we consider expedient to create the own view on classification of personal data of an individual in civil law of Ukraine. It is well-known fact that an individual as subject of civil legal relations has social and natural features that influence his or her legal status and in a certain way individualise him or her $[15 ; 16 ; 17]$. This is due to the dual nature of human as a biological and social being. Therefore, it is expedient to divide personal data of a person into biological and social (socio-political, legal). Biological should include information about morpho-physiological, biochemical and psychological characteristics of the person, namely: information about the state of health, sex, year of birth, physiological image, etc. Social personal data consists of information about the marital status, level of education, children, professional employment, citizenship, religion, 
political affiliation, public position, credit history of a person, conviction, legal obligations, etc.

This is a doctrinal classification of personal data, which allows determining their list in the static of legal relations. However, this is not enough, since the static does not reveal the functional meaning of a particular type of personal data of an individual for the purpose of its identification. Thus, based on the analysis of information about an individual in a group of biological or social personal data, it is impossible to identify a person and to determine the level of his or her legal personality. In order to improve providing the legal personality personification of an individual, we suggest following classification: nominative personal data of an individual, which are the surname, name, patronymic, date of birth, etc. as a basic condition for their classification, and also variable personal data of an individual - education, marital status, place of residence, etc., through which the content of information about a person is established, the possibility of a clearer identification of the individual in the "legal field" is achieved. Nominative personal data is static. Its purpose is to identify initially a subject based on his or her general characteristic.

Variable personal data can accumulate or change under the influence of reality, for example, to the passage of time. Consolidating with a nominative, they contribute to the achievement of the goal of personification of an individual. Exactly this information provides the ability of data about an individual to flow.

\section{CONCLUSIONS}

Consequently, the notion "personal data" should be understood as the data of a person who is identified or can be identified on the basis of this data or additional information that may fall into the controller of the data and which contain expressions of attitude towards that person and an indication of a particular purpose or plans for this person from the person controlling the data or another person. Current national legislation defined the notion of personal data: information or collection of information about the physical person who is identified or can be specifically identified. Social significance, participation in legal relations, with regard to the flow of this information, of a specific subject - the organiser of public information defines whether information belongs to the public category. Contents of the public information may constitute information, regardless of the sectorial belonging and type, resulting from the information activities of the authorities or other public information managers. Information providers of public information are subjects of power, legal entities, financed from state and local budgets, persons performing delegated powers, as well as economic entities. Information and legal status of public information providers, procedure of giving access to public information, which may be the subject of further research in this direction, require separate analysis.

In the research, legal classifications of types of information about an individual were analyzed. The matter of classification was researched by different scientists. 
The author identified that considered classification has a cross-sectorial nature, since the above listed personal data are systematised for the purpose of its use, including in the public law field (tax law, forensics, etc.). That is why in the author's opinion it is methodologically unacceptable. We consider erroneous to combine law phenomenon that have different fields of application, as well as the method of legal regulation of legal relations, in which they become the object of law, or legal means of their regulation.

Enforcing the right of an individual related to the processing of their personal data with the help of an effective institutional and legal mechanism should become the purpose improving the protection of personal data in Ukraine. Legal basis of personal data protection defined by framework law needs to be adapted to EU legal norms and further significant improvement.

\section{REFERENCES}

[1] Law of Ukraine "On Protection of Personal”. (2010). Retrieved from https://zakon.rada.gov.ua/laws/show/2297-17

[2] Law of Ukraine “On Information”. (1992). Retrieved from https://zakon.rada.gov.ua/ laws/show/2657-12

[3] Halfina, R. O. (1974). General theory of legal relations. Moscow: Yuridicheskaya literatura.

[4] Davidova, N. O. (2008). Personal non-property rights. Kyiv: In Yure.

[5] Nohrina, M. L. (2004). Civil law regulation of personal non-property relations, not related to property. Saint Petersburg: Izdatel'stvo V. Aslanova Yuridicheskiy tsentr Press.

[6] Ustimenko, N. V. (2003). Civil law protection of secrets of personal life of a person. Kharkov: PP Ton-Art.

[7] Krasavchikova, L. O. (1994). The concept and system of personal non-property, nonproperty rights of citizens (individuals) in the civil law of the Russian Federation. (Doctoral dissertation, Ural State Law Academy, Ekaterinburg, Russian Federation).

[8] Kechekyan, S. F. (1958). Legal Relations in a Socialist Society. Moscow: Publishing House of the Academy of Sciences of the USSR.

[9] Kulinich, O. O. (2006). Restricted information as an object of civil law. (Candidate thesis, Odessa, National University "Odessa Law Academy”, Odessa, Ukraine).

[10] Afanasyev, V. G. (1994). Social information. Moscow: Nauka.

[11] Bachilo, I. L., Lopatin, V. N., \& Fedotov, M. A. (2001). Information law. St. Petersburg: Yuridicheskiy tsentr Press.

[12] Kopylov, V. A. (1997). Information as an object of legal relations in the systems of private and public law. Scientific and Technical Information, 9, 1-17.

[13] Petrykina, N. I. (2011). Legal regulation of the circulation of personal data. In N. I. Petrykina (Ed.), Theory and practice (pp. 18-29). Moscow: Statut, 2011.

[14] Ishcheynov, V. Ya. (2006). Personal data in legislative and regulatory documents of the Russian Federation and information systems. Office Work, 3, 90.

[15] Berg, N., \& Kim, J.-Y. (2018). Free expression and defamation. Law, Probability and Risk, 17(3), 201-223.

[16] Goodman-Delahunty, J., \& Martschuk, N. (2018). Securing reliable information in investigative interviews: coercive and noncoercive strategies preceding turning points. Police 
Practice and Research. Retrieved from https://www.tandfonline.com/doi/full/10.1080/15 614263.2018.1531752

[17] Vrij, A., Meissner, C. A., Fisher, R. P., Kassin, S. M., Morgan, C. A., \& Kleinman, S. M. (2017). Psychological perspectives on interrogation. Perspectives on Psychological Science, 6, 927-955

\section{Hans Joachim Schramm}

Institute of Eastern Law

University of Technology, Business and Design

23966, 14 Philipp-Müller-Straße, Wismar, Germany

\section{Anatoly V. Kostruba}

Doctor of Law, Associate Professor, Professor

Department of Civil Law

Vasyl Stefanyk Precarpathian National University

76018, 57 Shevchenko Str., Ivano-Frankivsk, Ukraine

Suggested Citation: Schramm, H. J., \& Kostruba, A. V. (2019). Legal classification of types of information about an individual. Journal of the National Academy of Legal Sciences of Ukraine, 26 (1), 123-132.

Submitted: 09/01/2019

Revised: 05/02/2019

Accepted: 28/03/2019 